\title{
Biocompatible CuO-decorated carbon nanoplatforms for multiplexed imaging and enhanced antitumor efficacy via combined photothermal therapy/ chemodynamic therapy/chemotherapy
}

\author{
Fan Jiang ${ }^{1,2}$, Binbin Ding ${ }^{1,2}$, Yajie Zhao ${ }^{1,2}$, Shuang Liang ${ }^{1,2}$, Ziyong Cheng ${ }^{1,2}$, Bengang Xing ${ }^{3}$, \\ Bo Teng ${ }^{4}$, Ping'an $\mathrm{Ma}^{1,2^{*}}$ and Jun Lin ${ }^{1,2^{*}}$
}

\begin{abstract}
Inspired by the limitations of nanoparticles in cancer treatment caused by their low therapeutic effects and biotoxicity, biocompatible and photothermal enhanced copper oxide-decorated carbon nanospheres (CuO@CNSs) with doxorubicin hydrochloride (DOX) loading were constructed. CNSs as photothermal agents were synthesized by a hydrothermal reaction. $\mathrm{CuO}$ was adsorbed on the surface of CNSs, which improved the photothermal conversion efficiency due to the electron transitions between $\mathrm{C}-2 \mathrm{p}$ and $\mathrm{Cu}-3 \mathrm{~d}$. In addition, $\mathrm{CuO}$ would release $\mathrm{Cu}^{2+}$ ions in the tumor microenvironment, which could produce hydroxyl radical $(\cdot \mathrm{OH})$ to induce cancer cells apoptosis via Haber-Weiss and Fenton-like reactions. DOX as a chemotherapeutic agent was located on the surface of $\mathrm{CuO} @ \mathrm{CNSs}$ by electrostatic adsorption and released quickly in the tumor microenvironment to kill cancer cells. The CuO@CNSs-DOX nanoplatforms realized the combination therapy of photothermal therapy (PTT), chemodynamic therapy (CDT), and chemotherapy (CT), which have strong potential for cancer treatment.
\end{abstract}

Keywords: $\mathrm{CuO}$, carbon nanospheres, enhanced photothermal therapy, chemodynamic therapy, chemotherapy

\section{INTRODUCTION}

Cancer is a serious threat to human health. Chemotherapy (CT) is considered to be the most commonly used treatment. However, CT has many disadvantages such as drug resistance and severe side effects, which limit its wide- spread use $[1,2]$. Photothermal therapy (PTT) has attracted much attention worldwide due to its low cost and ignorable side effect [3-5]. Upon near-infrared (NIR) irradiation, photothermal reagents can rapidly convert light into heat to kill cancer cells through hyperthermia. Carbon-based materials [6-9] exhibit great potential as photothermal agents because of their unique optical features, good biocompatibility, and low biotoxicity. However, the therapeutic effect of carbon-based materials is hindered due to the low photothermal conversion efficiency.

Chemodynamic therapy (CDT) has been widely studied recently. A large amount of hydroxyl radicals $(\cdot \mathrm{OH})$ could be produced to accelerate cancer cell apoptosis via the reaction between the tumor microenvironment and CDT agent. Some metal (iron [10-12], copper [10,13-15], manganese [16-18], silver [17,19]) ions have been reported to produce $\mathrm{OH}$ by catalyzing hydrogen peroxide in the tumor microenvironment. For instance, our group [16] developed a nanoplatform with in-situ growth of $\mathrm{MnO}_{2}$ on the surfaces of upconversion nanoparticles (UCNPs). $\mathrm{MnO}_{2}$ released $\mathrm{Mn}^{2+}$ in the tumor microenvironment, and the released $\mathrm{Mn}^{2+}$ can produce $\cdot \mathrm{OH}$ by a Fenton-like reaction. However, as the reaction proceeds, the $\mathrm{H}_{2} \mathrm{O}_{2}$ content in the microenvironment decreases and the therapeutic effect is limited. Therefore, to solve this problem and achieve the best therapeutic effect, combination therapy has proved to be an attractive strategy.

Among various combination treatments, the combina-

\footnotetext{
${ }^{1}$ State Key Laboratory of Rare Earth Resource Utilization, Changchun Institute of Applied Chemistry, Chinese Academy of Sciences, Changchun 130022, China

${ }^{2}$ University of Science and Technology of China, Hefei 230026, China

${ }^{3}$ School of Physical \& Mathematical Sciences, Nanyang Technological University, Singapore

${ }^{4}$ Department of Otolaryngology Head and Neck Surgery, The Second Hospital, Jilin University, Changchun 130041, China

* Corresponding authors (emails: mapa675@ciac.ac.cn (Ma P); jlin@ciac.ac.cn (Lin J))
} 
tion of PTT, CDT and CT multi-mode treatment platforms has attracted much attention [20,21]. Multifunctional nanoplatforms DOX@Fe(III)@WS - -PVP (DOX, doxorubicin hydrochloride; PVP, polyvinylpyrrolidone) were synthesized by $\mathrm{Wu}$ et al. [22]. $\mathrm{WS}_{2}$ acted as a photothermal agent. $\mathrm{Fe}(\mathrm{III})$ reacted with $\mathrm{WS}_{2}$ to form $\mathrm{Fe}^{2+}$ and $\mathrm{WO}_{4}{ }^{2-}$, and then $\mathrm{Fe}^{2+}$ catalyzed $\mathrm{H}_{2} \mathrm{O}_{2}$ in tumor cells to produce $\mathrm{OH}$ via the Fenton reaction. DOX was released rapidly at the tumor site. Magnetic $\mathrm{Co}_{3} \mathrm{O}_{4}$-DOX was also synthesized for multi-mode theranostics of cancer [23]. $\mathrm{Co}_{3} \mathrm{O}_{4}$ acted as the photothermal agent and released $\mathrm{Co}^{3+}$ to produce $\mathrm{OH}$ in the tumor microenvironment. DOX was also released at the same time to kill tumor cells. In brief, the multi-mode treatment platforms have been proved to exhibit excellent anticancer efficacy.

Here we designed multifunctional nanoplatforms $\mathrm{CuO@}$ CNSs-DOX (CNSs=carbon nanospheres) to realize the combination therapy of PTT, CDT, and CT. To our knowledge, it is the first report on integrating semiconductor $\mathrm{CuO}$ and biocompatible CNSs into $\mathrm{CuO} @ \mathrm{CNSs}$ nanocomposites for cancer treatment. CNSs as photothermal agents were prepared by hydrothermal reaction [24]. $\mathrm{CuO}$ was adsorbed on the surface of CNSs, which not only served as a CDT agent but also improved the photothermal conversion efficiency of nanoparticles. DOX was loaded on the surface of $\mathrm{CuO} @ \mathrm{CNSs}$ by electrostatic adsorption and released at the tumor site. Besides, CuO@CNSs can be used for infrared (IR) thermal imaging and photoacoustic (PA) imaging, which provided the real-time diagnosis for diseases [25,26]. The multifunctional nanoplatforms have good antitumor effect in vitro and in vivo, which are promising to be used in cancer treatment.

\section{EXPERIMENTAL SECTION}

\section{Preparation of CNSs and CuO@CNSs}

The CNSs were prepared via a hydrothermal method [24]. In a nutshell, glucose was dissolved in deionized water. The mixture were transformed into an autoclave and maintained at $180^{\circ} \mathrm{C}$ for $6 \mathrm{~h}$. The products were separated by centrifugation and dried in vacuum at $60^{\circ} \mathrm{C}$.

For obtaining CuO@CNSs, CNSs (0.1 g) were dispersed in $5 \mathrm{~mL}$ of water, and $\mathrm{CuCl}_{2} \cdot 2 \mathrm{H}_{2} \mathrm{O}(0.0862 \mathrm{~g})$ was added into the solution and stirred at room temperature for $4 \mathrm{~h}$. The CuO@CNSs were centrifuged at 10,000 $\mathrm{r} \mathrm{min}^{-1}$ for $10 \mathrm{~min}$ and washed with ethanol and water. The products were dried in vacuum at $60^{\circ} \mathrm{C}$.

The release of $\mathrm{Cu}^{2+}$ from $\mathrm{CuO} @ \mathrm{CNSs}$

$\mathrm{CuO} @ \mathrm{CNSs}(5 \mathrm{mg})$ were dispersed in $2 \mathrm{~mL}$ of phosphate buffer saline (PBS) with different $\mathrm{pH}(7.4,6.5$ and 5.0) at a certain amount of time. The supernatants were obtained by centrifugation and replaced by the same amount of fresh PBS solution. The mass of released $\mathrm{Cu}^{2+}$ ions was tested by inductively coupled plasma mass spectrometry (ICP-MS).

\section{Extracellular $\cdot \mathbf{O H}$ detection}

$\mathrm{NaOH}(0.4 \mathrm{~g})$ was dissolved in $50 \mathrm{~mL}$ of deionized water to form a transparent solution. Then $0.8307 \mathrm{~g}$ terephthalic acid (TAOH) was added to form a homogeneous solution. The fluorescence at $430 \mathrm{~nm}$ of the solution $\left(\mathrm{H}_{2} \mathrm{O}\right.$ +TAOH, TAOH+8 mmol L ${ }^{-1} \mathrm{H}_{2} \mathrm{O}_{2}, \mathrm{CuO} @ \mathrm{CNSs}+\mathrm{TAOH}$, $\mathrm{CuO} @ \mathrm{CNSs}+\mathrm{TAOH}+8 \mathrm{mmol} \mathrm{L}^{-1} \mathrm{H}_{2} \mathrm{O}_{2}$ ) was determined using an F7000 fluorescence spectrometer after removal of the nanoparticles by centrifugation.

To assess the connection between the amount of produced $\cdot \mathrm{OH}$ and the concentration of $\mathrm{H}_{2} \mathrm{O}_{2}$, different concentrations of $\mathrm{H}_{2} \mathrm{O}_{2}\left(0,2,4,8\right.$, and $\left.16 \mathrm{mmol} \mathrm{L}^{-1}\right)$ were mixed with CuO@CNSs (200 ppm). The fluorescence of the solution at $430 \mathrm{~nm}$ was observed after removal of the nanoparticles by centrifugation.

To assess the connection between the amount of produced $\cdot \mathrm{OH}$ and $\mathrm{pH}$ of the environment, $\mathrm{CuO} @ \mathrm{CNSs}$ ( $2 \mathrm{mg}$ ) were dispensed in PBS ( $\mathrm{pH} 7.4,6.5$ and 5.0), and then $\mathrm{TAOH}$ was added into the solution. The fluorescence of the mixture at $430 \mathrm{~nm}$ was observed after removal of the nanoparticles by centrifugation.

\section{Intracellular $\cdot \mathbf{O H}$ detection}

$4 \mathrm{~T} 1$ cells were seeded on 12-well plates at a density of $6 \times 10^{4}$ cells per well and treated with (i) Control; (ii) CNSs; (iii) CuO@CNSs. After incubation at $37^{\circ} \mathrm{C}$ for $4 \mathrm{~h}$, the cells were washed with $\mathrm{PBS}$, and ROS probe was added to each well and incubated at $37^{\circ} \mathrm{C}$ for $30 \mathrm{~min}$. Finally, the cells were washed with PBS and observed by a florescence microscope system (Nikon Ti-S).

\section{Photothermal properties}

CuO@CNSs (0, 50, 100, 200, 400, and 800 ppm, $0.2 \mathrm{~mL})$ were exposed to the 808 -nm NIR laser $\left(2 \mathrm{~W} \mathrm{~cm}^{-2}\right)$ for $10 \mathrm{~min}$ in 96-well plates, an IR thermal camera (S6-a, IRS, China) was used to record the change of temperature. In addition, CuO@CNSs solutions were irradiated by 808-nm NIR laser $\left(2 \mathrm{~W} \mathrm{~cm}^{-2}\right)$ for $5 \mathrm{~min}$ and cooled for $5 \mathrm{~min}$, and the process lasted five cycles to investigate the photothermal stability.

\section{Photothermal conversion efficiency}

CuO@CNSs solution (200 ppm, $1 \mathrm{~mL}$ ) was added in a 
cuvette and irradiated by NIR laser $(808 \mathrm{~nm}, 2 \mathrm{~W} \mathrm{~cm}$, $10 \mathrm{~min}$ ), and then naturally cooled for another $10 \mathrm{~min}$. The change of temperature was recorded every $30 \mathrm{~s}$. The photothermal conversion efficiency of aqueous CNSs solution $(1 \mathrm{~mL}, 200 \mathrm{ppm})$ was measured in the same way.

\section{Live/dead cell staining}

Calcein-AM and propidium iodide (PI) were used to assess the photothermal performance. $4 \mathrm{~T} 1$ cells were incubated with CuO@CNSs $(0,25,50,100$, and 200 ppm) and exposed to NIR laser irradiation $\left(808 \mathrm{~nm}, 2 \mathrm{~W} \mathrm{~cm}^{-2}\right.$, $10 \mathrm{~min}$ ), and then the cells were co-stained with Calcein AM (green, live cells) and PI following the manufacturer's instructions (BestBio, Shanghai, China).

\section{Computational details}

The calculations were based on density functional theory (DFT) with the Perdew-Burke-Ernzerbof (PBE) form of generalized gradient approximation functional (GGA). The Vienna Ab-Initio Simulation Package (VASP) was employed. The cut off of plane wave energy was set as $400 \mathrm{eV}$. The Fermi scheme was shown for electron occupancy with an energy smearing of $0.1 \mathrm{eV}$. The energy and force were set as $1.0 \times 10^{-6} \mathrm{eV} /$ atom and $0.01 \mathrm{eV} \AA^{-1}$, respectively for geometry optimization. All calculations included the spin polarization.

\section{Loading of DOX}

$\mathrm{CuO} @ \mathrm{CNSs}(5 \mathrm{mg})$ were dispersed in $2 \mathrm{~mL}$ of deionized water and mixed with $2 \mathrm{~mL}$ of DOX solution $\left(1 \mathrm{mg} \mathrm{mL}^{-1}\right)$. The solution was stirred for $24 \mathrm{~h}$ in dark. ThenCuO@CNSs-DOX was obtained by centrifugation. The supernatant was collected and tested by ultravioletvisible (UV-Vis) spectrometry. Loading efficiency of DOX was calculated by using the following equation: loading efficiency $=$ (weight of loaded DOX)/(weight of (loaded DOX+CuO@CNSs)) $\times 100 \%$.

\section{Release behavior of DOX}

CuO@CNSs-DOX (5 mg) were dispensed in $2 \mathrm{~mL}$ of PBS

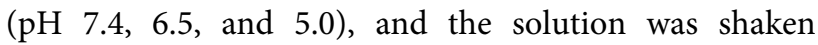
slightly at $37^{\circ} \mathrm{C}$.

To explore the photothermal-triggered DOX release, the solution was irradiated by $808-\mathrm{nm}$ NIR laser for $10 \mathrm{~min}$ at specific time points. The supernatants were obtained by centrifugation and the absorbance at the wavelength of $480 \mathrm{~nm}$ was measured by UV-Vis spectrometry.

\section{Cellular uptake}

$4 \mathrm{~T} 1$ cells were seeded into 12 -well plates $\left(1 \times 10^{4}\right.$ cells per well) and incubated with CuO@CNSs-DOX for different times $(10 \mathrm{~min}, 1$ and $4 \mathrm{~h}$ ), and then the fluorescence microscope was used for cell imaging. ICP-MS was also used to detect the cellular uptake. 4T1 cells were seeded in 6-well plates $\left(3 \times 10^{5}\right.$ cells per well $)$ and cultured with $\mathrm{CuO} @ \mathrm{CNSs}$ at $37^{\circ} \mathrm{C}$ for $10 \mathrm{~min}, 1$ and $4 \mathrm{~h}$, respectively. The cells were washed with $\mathrm{PBS}$ to remove excess CuO@CNSs and lysed using cell lysis buffer. The mass of copper content was determined by ICP-MS.

\section{Biocompatibility of CuO@CNSs}

L929 and 4T1 cells were seeded into 96-well plates $\left(6 \times 10^{3}\right.$ cells per well) and cultured with different concentrations $\left(0,12.5,25,50,100\right.$, and $\left.200 \mu \mathrm{g} \mathrm{m}^{-1}\right)$ of $\mathrm{CuO} @ \mathrm{CNSs}$. After incubation overnight, standard 3-(4,5-dimethylthiazol-2-yl)-2,5-diphenyltetrazolium bromide (MTT) assay was used to measure the cell viability.

\section{In vitro cytotoxicity detection}

The cytotoxicity of $\mathrm{CuO} @ \mathrm{CNSs}-\mathrm{DOX}$ was performed on 4T1 cells by the MTT test. 4T1 cells were seeded into 96well plates $\left(5 \times 10^{3}\right.$ cells per well). After overnight incubation, fresh Dulbecco's modified Eagle medium (DMEM) containing CuO@CNSs, pure DOX or CuO@CNSs-DOX was added into the plates. The cells were washed with PBS after 4-h incubation, and then exposed to NIR light $\left(2 \mathrm{~W} \mathrm{~cm}^{-2}\right)$ for $5 \mathrm{~min}$. MTT assay was used to measure the cell viability.

\section{Flow cytometry}

Flow cytometry was also performed to analyze the cytotoxicity of $\mathrm{CuO} @ \mathrm{CNSs}-\mathrm{DOX}$. 4T1 cells were seeded into 6-well plates $\left(3 \times 10^{5}\right.$ cells per well) and incubated with

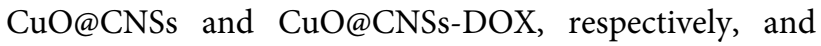
then exposed to $808 \mathrm{~nm}$ laser for $10 \mathrm{~min}$. Annexin VFITC and PI were used to stain the cells following the manufacturer's instructions (BestBio, Shanghai, China).

\section{Animal experiments}

All experiments of mice were approved by the Institutional Animal Care and Use Committee of Jilin University. Six-eight-week-old female Balb/c mice were purchased from the Center for Experimental Animals, Jilin University (Changchun, China).

\section{IR and PA imaging}

In vitro imaging was acquired by dissolution of $\mathrm{CuO@CNSs} \mathrm{in} \mathrm{water} \mathrm{with} \mathrm{different} \mathrm{concentrations.} \mathrm{For} \mathrm{in}$ vivo imaging, 4T1-bearing mice were intratumorally injected with CuO@CNSs. IR thermal images and a pre- 
clinical photoacoustic computed tomography scanner (Endra Nexus 128, USA) were used to obtain IR and PA imaging.

\section{Anti-tumor experiment}

$\mathrm{Balb} / \mathrm{c}$ mice were injected with $4 \mathrm{~T} 1$ cells in the left axilla. After $7 \mathrm{~d}$, the tumor diameter reached $6-10 \mathrm{~mm}$. The mice were randomly divided into six groups (six mice in each group): (i) PBS as control group; (ii) $\mathrm{CuO@CNSs;}$ (iii) $\mathrm{CuO@CNSs+NIR;} \mathrm{(iv)} \mathrm{pure} \mathrm{DOX;} \mathrm{(v)} \mathrm{CuO@CNSs-}$ DOX; (vi)CuO@CNSs-DOX+NIR. The mice were intratumorally injected with the above materials and exposed to 808 -nm NIR irradiation $\left(2 \mathrm{~W} \mathrm{~cm}^{-2}, 10 \mathrm{~min}\right)$ after injection for $3 \mathrm{~h}$. The tumor sizes and weights of mice were measured every two days, and the tumor volumes were calculated with the formula of $V=$ (tumor length $) \times($ tumor width $)^{2} / 2$.

\section{Biocompatibility in vivo}

Mice were executed after tumor therapy. Major organs of the mice (heart, liver, spleen, lung and kidney) were collected, fixed in $4 \%$ polyformaldehyde, embedded in paraffin, sliced and stained with hematoxylin and eosin $(\mathrm{H} \& \mathrm{E})$, and photographed using a biological microscope (BX-53, Olympus, Japan).

\section{Statistical analysis}

All the data were analyzed by the Statistical Program for Social Sciences software (SPSS, USA). All data were expressed as means (standard deviation), and statistical difference was considered to be present at $p<0.05$. Except as mentioned, all assays were repeated in triplicate in three independent experiments.

\section{RESULTS AND DISCUSSION}

\section{Fabrication and characterization}

The synthesis procedures and anti-cancer mechanism are illustrated in Scheme 1. The CNSs were synthesized via the solvothermal method [24]. The $\mathrm{Cu}^{2+}$ was adsorbed on the surface of CNSs and reacted with dissolved oxygen in water to produce $\mathrm{CuO}$ in vacuum. DOX was introduced to the surface of $\mathrm{CuO} @ \mathrm{CNS}$ s by electrostatic adsorption. Scanning electron microscopy (SEM) (Fig. 1a) and

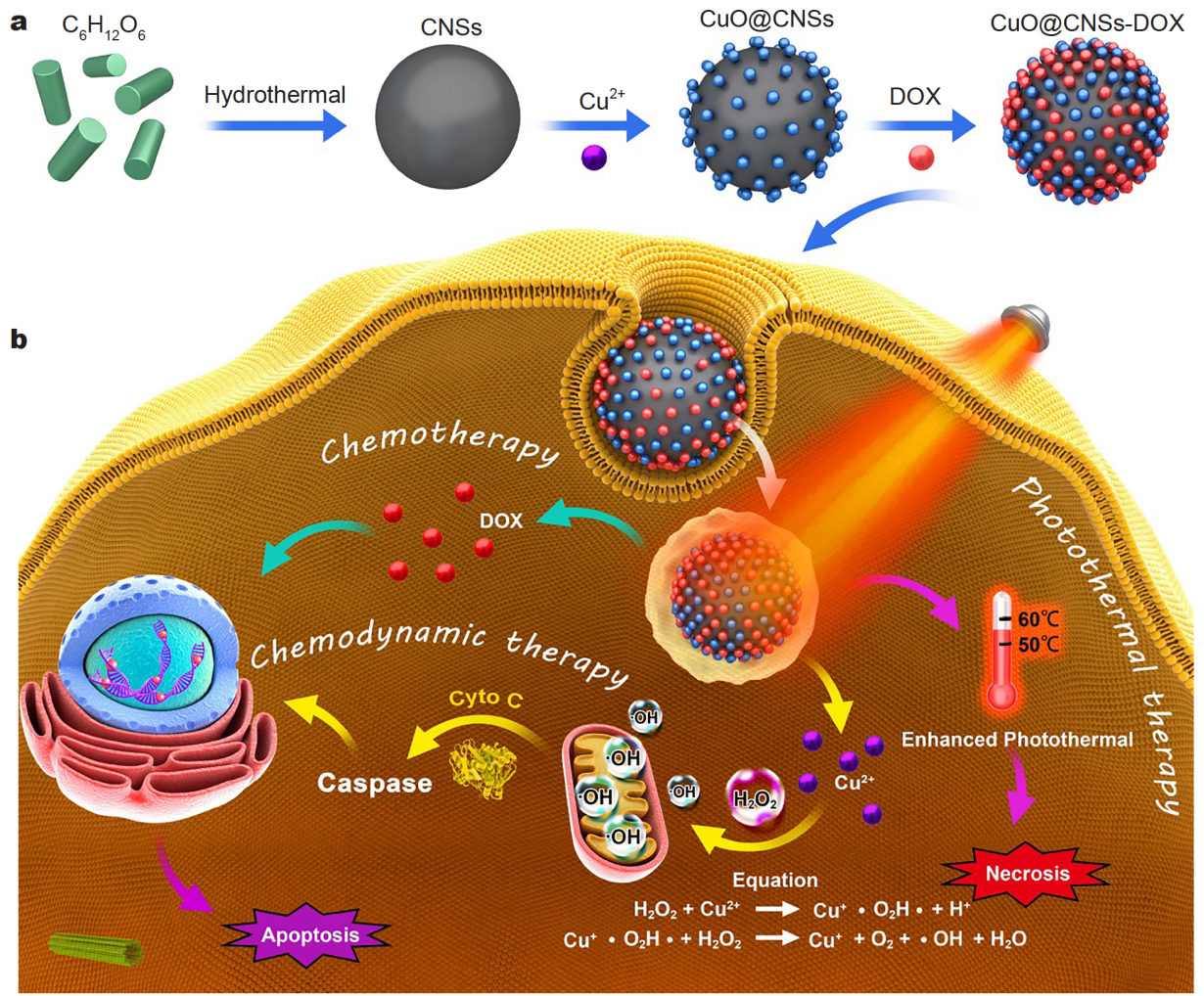

Scheme 1 (a) Schematic illustration of the preparation process of the CuO@CNSs-DOX nanoplatforms. CNSs were synthesized via the solvothermal method. $\mathrm{CuO}$ was adsorbed onto the CNSs, and DOX was loaded onto the surface of CuO@CNSs by electrostatic adsorption. (b) Schematic illustration of the endocytosis of CuO@CNSs-DOX nanoplatforms for PTT, CDT, and CT. 
transmission electron microscopy (TEM) (Fig. 1b) images confirm that the $\mathrm{CuO} @ \mathrm{CNSs}$ have uniformed spherical structure with an average size of $150 \mathrm{~nm}$. Fig. S1 displays that the hydrodynamic diameters of CuO@CNSs were $150-200 \mathrm{~nm}$, which are suitable to accumulate in tumor cells via the enhanced permeability and retention (EPR) effect. In addition, the dynamic light scattering (DLS) diameters of $\mathrm{CuO} @ \mathrm{CNSs}$ dispersed in water, PBS, culture medium (DMEM) and fetal calf serum were tested to explore the stability of $\mathrm{CuO} @ \mathrm{CNSs}$, respectively. As shown in Fig. S2a-d, these DLS diameters do not show any significant change after $3 \mathrm{~d}$ of storage, clearly demonstrating the stability of $\mathrm{CuO} @ \mathrm{CNSs}$.

The structure of nanoparticles was verified by X-ray diffraction (XRD) (Fig. 1f). The wide-angle peak at $22^{\circ}$ was the characteristic peak of CNSs and no defined diffraction peaks of $\mathrm{CuO}$ were observed [27], demonstrating that the nanoparticles have poor crystallinity. The elemental compositions of $\mathrm{CuO} @ \mathrm{CNSs}$ were detected by energy dispersive X-ray (EDX) mapping (Fig. 1c-e) and
X-ray photoelectron spectroscopy (XPS) (Fig. S3), proving that the elemental $\mathrm{Cu}$ was bound to CNSs. In Fig. $1 \mathrm{~h}$, the peak at $532.1 \mathrm{eV}$ corresponded to $\mathrm{O}^{2-}$. In Fig. $1 \mathrm{~g}$, peaks at 934 and $955 \mathrm{eV}$ corresponded to $\mathrm{Cu}$ (II) $2 \mathrm{p}_{3 / 2}$ and $\mathrm{Cu}(\mathrm{II}) 2 \mathrm{p}_{1 / 2}$, respectively. Two satellite peaks at 943 and $962 \mathrm{eV}$ were the characteristic peaks of $\mathrm{CuO}$ [28]. These results confirmed that the $\mathrm{Cu}$ in the form of $\mathrm{CuO}$ was bound to carbon spheres. The evolution of zeta potential confirmed the successful modification in each preparation step (Fig. 2a). After decoration with negatively charged $\mathrm{CuO}$, the zeta potential of nanoparticles decreased from -24.5 to $-28.4 \mathrm{mV}$, and the zeta potential was increased to $-19.4 \mathrm{mV}$ after further adsorption of positively charged DOX. The specific surface areas of CNSs and CuO@CNSs via the $\mathrm{N}_{2}$ adsorption and desorption were $33.37 \mathrm{~m}^{2} \mathrm{~g}^{-1}$ (Fig. 2b) and $43.307 \mathrm{~m}^{2} \mathrm{~g}^{-1}$ (Fig. 2c), respectively, confirming that there were no obvious changes in surface area before and after the adsorption of $\mathrm{CuO}$.

The functional groups of $\mathrm{CuO} @ \mathrm{CNSs}$ were identified
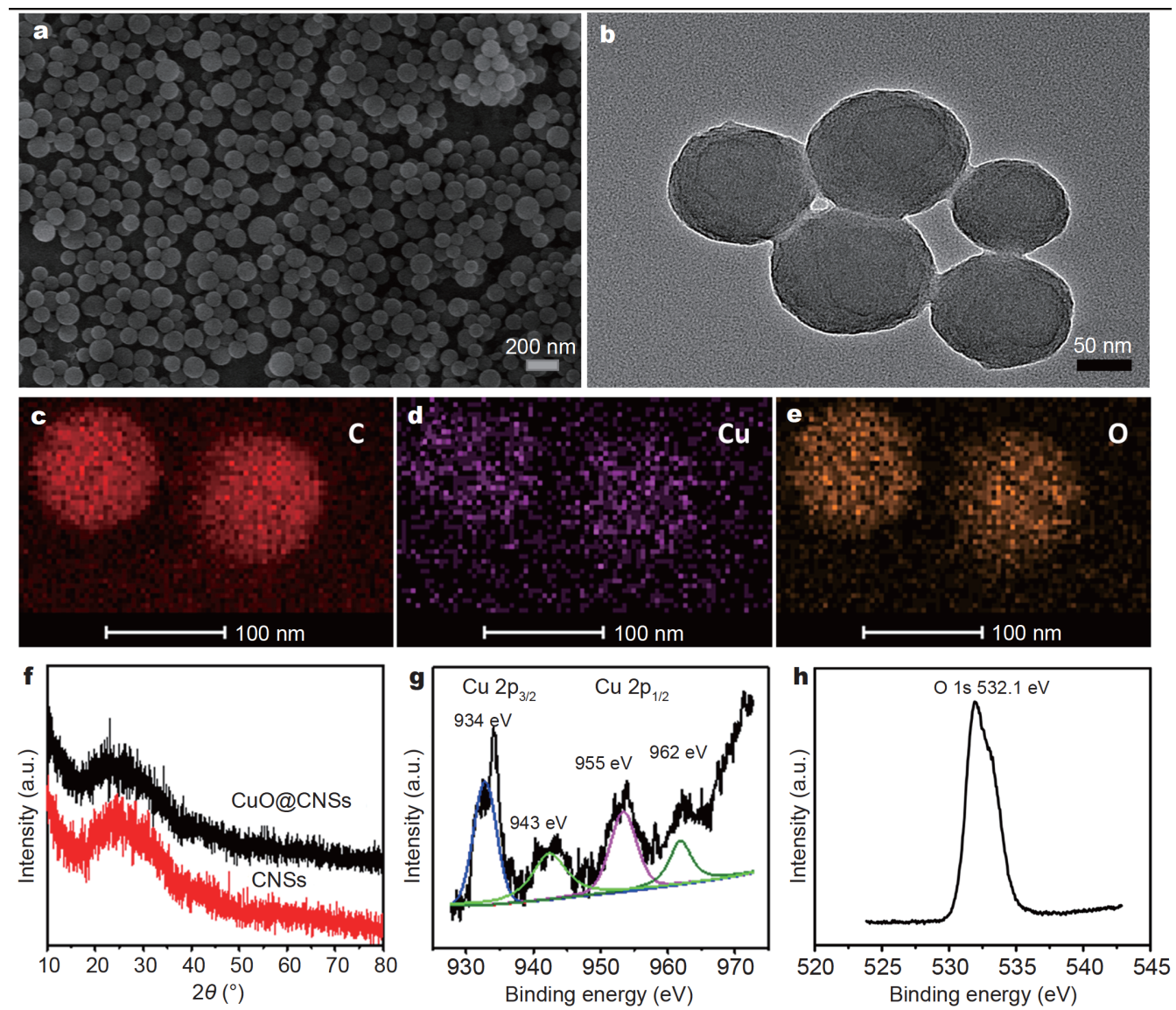

Figure 1 (a) SEM and (b) TEM images of CuO@CNSs. The elemental mappings of (c) C, (d) Cu, and (e) O of CuO@CNSs. (f) XRD patterns of CNSs and CuO@CNSs. XPS spectra of (g) Cu 2p and (h) O 1s. 

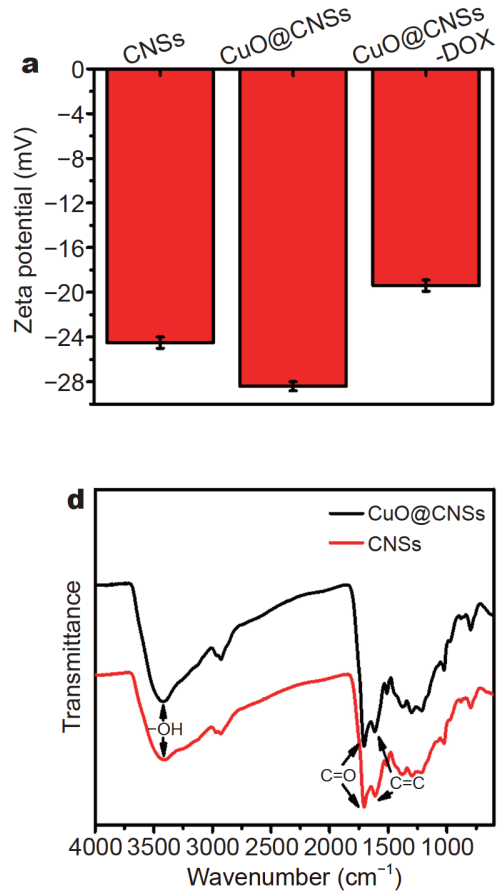
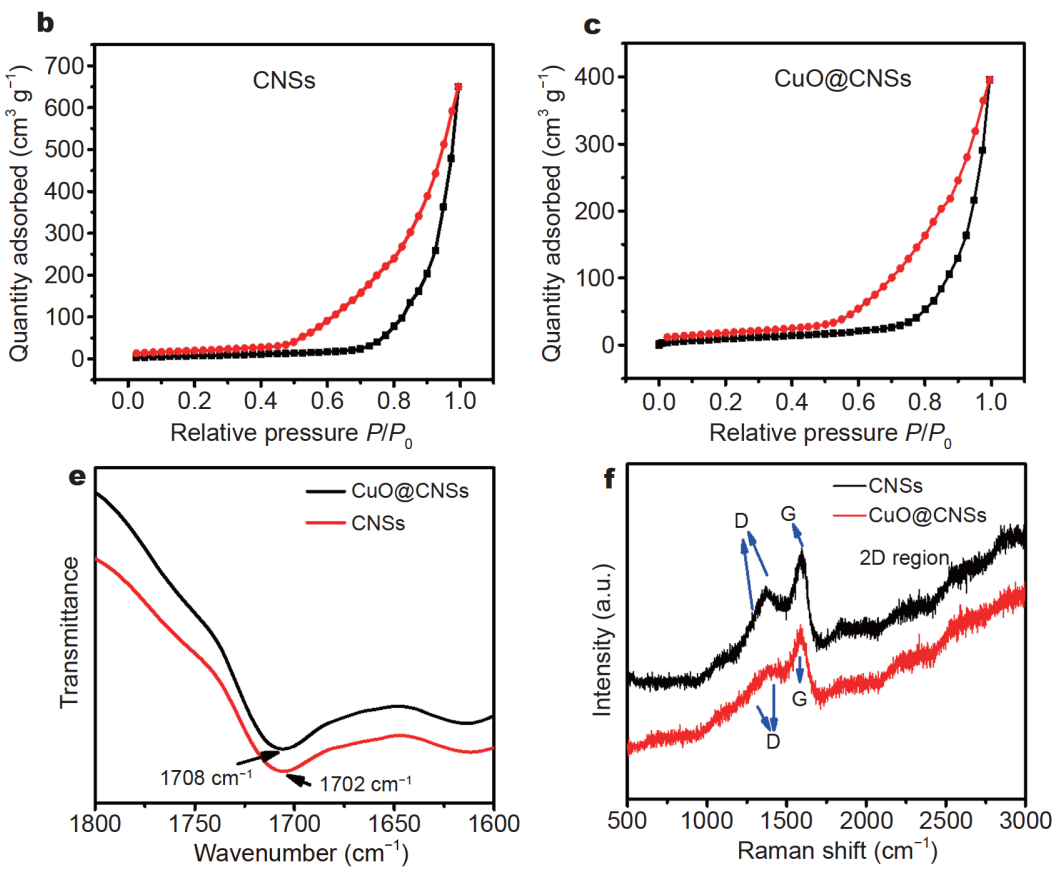

Figure 2 (a) Zeta potentials of CNSs, CuO@CNSs and CuO@CNSs-DOX dispersed in water. $\mathrm{N}_{2}$ adsorption-desorption isotherms of (b) CNSs and (c) CuO@CNSs. (d) FTIR spectra of CNSs and CuO@CNSs with functional groups. (e) Expanded FTIR spectra of CNSs and CuO@CNSs in the wavenumber range of $1800-1600 \mathrm{~cm}^{-1}$. (f) Raman spectra of CNSs and CuO@CNSs.

via Fourier transform infrared (FTIR) spectra. The connection between $\mathrm{CuO}$ and CNSs caused the movement of the peak from 1702 to $1708 \mathrm{~cm}^{-1}$ (Fig. 2e) [29]. Peaks at $3300-3500 \mathrm{~cm}^{-1}$ corresponded to the $\mathrm{OH}$ stretching (Fig. 2d), confirming that there were many hydroxyl groups on the surface of nanoparticles [30]. The above results indicate that the CuO@CNSs have good hydrophilicity. Raman spectra of CNSs and CuO@CNSs were also measured (Fig. 2f). The D peaks of CNSs located at 1340 and $1430 \mathrm{~cm}^{-1}$ shift to 1360 and $1450 \mathrm{~cm}^{-1}$ for CuO@CNSs, respectively. The red shift of the $\mathrm{D}$ peaks was due to the breathing of $\mathrm{sp}^{2}$ rings caused by defects [31]. The $\mathrm{G}$ peak of CNSs located at $1603 \mathrm{~cm}^{-1}$ shifts to $1580 \mathrm{~cm}^{-1}$ for CuO@CNSs, which is due to the stretch of $\mathrm{C} \mathrm{sp}^{2}$ atoms. The above results also prove that the $\mathrm{CuO}$ nanoparticles were adsorbed onto CNSs [32-34].

\section{The $\mathrm{pH}$-sensitive release of $\mathrm{Cu}^{2+}$ and production of $\cdot \mathrm{OH}$} $\mathrm{CuO}$ can release $\mathrm{Cu}^{2+}$ in an acidic environment. ICP-MS was used to detect the concentration of $\mathrm{Cu}^{2+}$ ions. We measured the release of $\mathrm{Cu}^{2+}$ at different $\mathrm{pH}(7.4,6.5$, and 5.0) (Fig. 3a), which corresponded to the blood environments $(\mathrm{pH}$ 7.4), tumor microenvironment ( $\mathrm{pH} 6.5)$ and intracellular condition ( $\mathrm{pH}$ 5), respectively [35]. Only about $20 \% \mathrm{Cu}^{2+}$ ions were released within $10 \mathrm{~h}$ at $\mathrm{pH}$ 7.4. About $40 \%$ and $80 \%$ copper ions were released at $\mathrm{pH} 6.5$ and $\mathrm{pH}$ 5.0, respectively, which were almost two and four times as much as the amount of copper ions released at $\mathrm{pH}$ 7.4. The results confirmed that the release of copper ions was $\mathrm{pH}$-dependent. SEM was used to observe the change of morphology at different $\mathrm{pH}(7.4,6.5$, and 5.0) (Fig. S4). With the decrease of $\mathrm{pH}$, the morphology of the material was destroyed more seriously. The above results proved that the $\mathrm{Cu}^{2+}$ ions can be selectively released to tumor sites, which can alleviate the damage to normal tissues. It is generally known that the iron-initiated Fenton chemistry can kill tumor cells via converting endogenous $\mathrm{H}_{2} \mathrm{O}_{2}$ into $\cdot \mathrm{OH}$ [22]. $\mathrm{Cu}^{2+}$-mediated HaberWeiss and Fenton-like reactions to generate $\cdot \mathrm{OH}$ like $\mathrm{Fe}^{2+}$ were also reported [36]. Here, to verify the $\cdot \mathrm{OH}$ generation, $\mathrm{TAOH}$, which can capture $\cdot \mathrm{OH}$ to produce strong fluorescent hydroxylation product 2-hydroxyterephthalic acid, was chosen to indirectly measure the amount of $\cdot \mathrm{OH}$ $[37,38]$. As exhibited in Fig. $3 \mathrm{~b}, \mathrm{Cu}^{2+}$ can produce $\cdot \mathrm{OH}$ by catalyzing hydrogen peroxide.

Electron spin resonance (ESR) technique was employed to monitor the $\mathrm{OH}$ production with 5,5'-dimethylpyrroline-1-oxide (DMPO) as the spin trap agent. As displayed in Fig. S5, the ESR signal of. $\mathrm{OH}$ radical with 

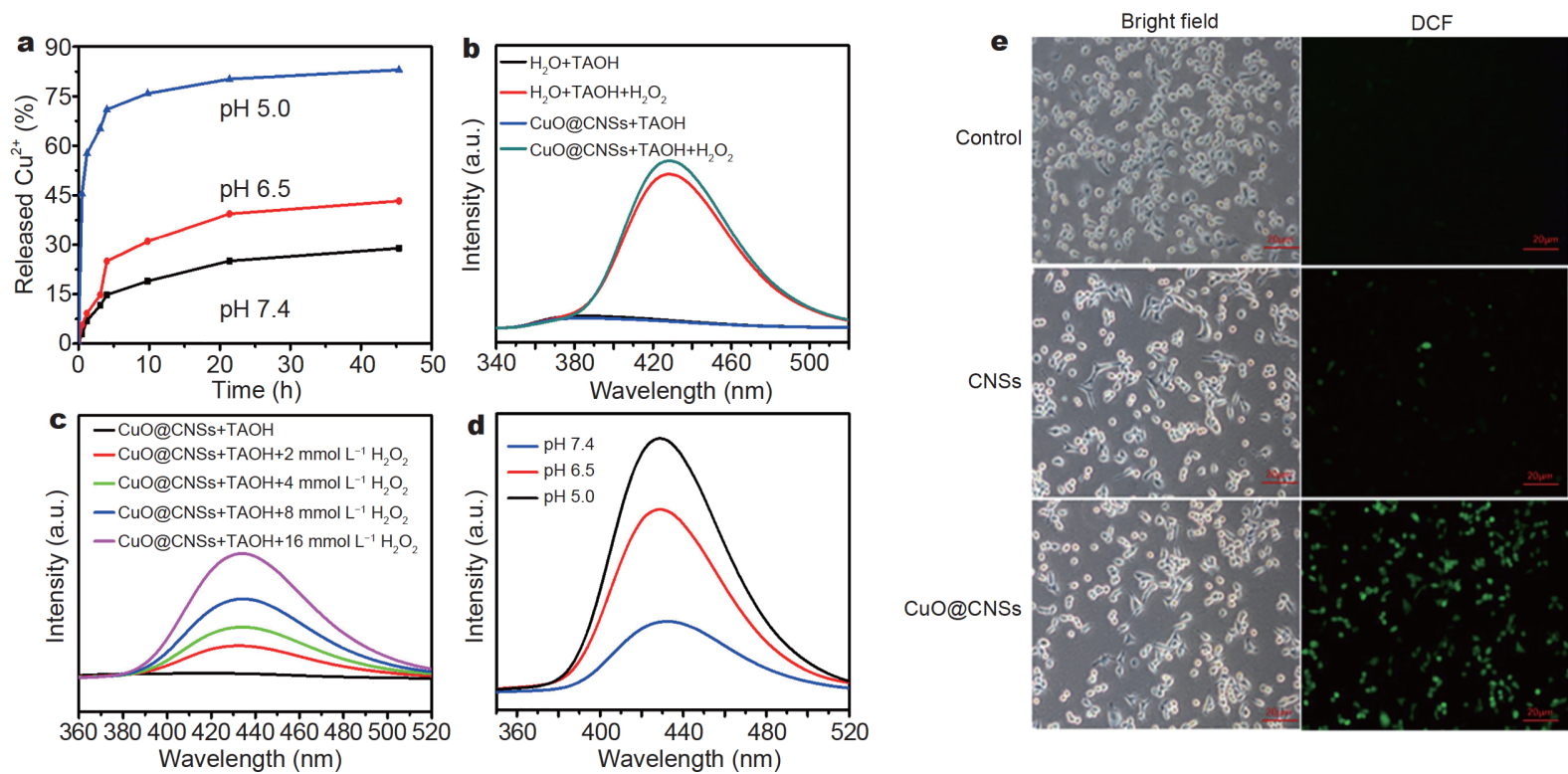

Figure 3 (a) The released $\mathrm{Cu}^{2+}$ from $\mathrm{CuO} @ \mathrm{CNSs}$ at different $\mathrm{pH}(7.4,6.5$, and 5.0). (b) The production of hydroxyl radicals in different solutions. (c) The production of hydroxyl radicals with different concentrations of $\mathrm{H}_{2} \mathrm{O}_{2}\left(0,2,4,8\right.$, and $\left.16 \mathrm{mmol} \mathrm{L}^{-1}\right)$. (d) The production of hydroxyl radicals at different $\mathrm{pH}(7.4,6.5$, and 5.0). (e) Intracellular production of hydroxyl radicals with different treatments, including control, CNSs and CuO@CNSs.

the typical peak intensity of 1:2:2:1 was observed in the $\mathrm{CuO@CNSs} \mathrm{and} \mathrm{H}_{2} \mathrm{O}_{2}$ mixed solution, further confirming the generation of $\cdot \mathrm{OH}$. Besides, the $\cdot \mathrm{OH}$ generation was $\mathrm{H}_{2} \mathrm{O}_{2}$ concentration-dependent (Fig. 3c). With the increase of $\mathrm{H}_{2} \mathrm{O}_{2}$ concentration, the absorption intensity of $\mathrm{TAOH}$ increased, indicating that more $\cdot \mathrm{OH}$ radicals were generated. In addition, the $\cdot \mathrm{OH}$ generation was also pH-dependent (Fig. 3d). With the decrease of $\mathrm{pH}$, more copper ions were released, which can produce more $\cdot \mathrm{OH}$ by $\mathrm{Cu}^{2+}$-mediated Haber-Weiss and Fenton-like reactions.

2,7-Dichlorodihydrofluorescein (DCFH-DA) which can be oxidized to $2^{\prime}, 7^{\prime}$-dichlorofluorescein (DCF) with green fluorescence by the generated $\cdot \mathrm{OH}$ was used to examine the $\cdot \mathrm{OH}$ in $4 \mathrm{~T} 1$ cells. As exhibited in Fig. 3e, stronger green fluorescence can be observed in $\mathrm{CuO@CNSs} \mathrm{group} \mathrm{compared} \mathrm{with} \mathrm{the} \mathrm{control} \mathrm{and} \mathrm{CNSs}$ groups, confirming that more $\cdot \mathrm{OH}$ radicals were generated in cells via $\mathrm{Cu}^{2+}$ mediated Haber-Weiss and Fentonlike reactions.

\section{Photothermal effects of $\mathrm{CuO} @ \mathrm{CNSs}$}

Compared with CNSs, the $\mathrm{CuO} @ \mathrm{CNSs}$ displayed enhanced NIR absorption and photothermal properties (Fig. 4a, b). The photothermal conversion efficiency (Fig. S6) of CuO@CNSs (10.14\%) was also higher than that of CNSs (6.7\%).
To find out the cause of photothermal enhancement, the band gap properties of CNSs and CuO@CNSs were calculated based on UV-Vis spectra. As shown in Fig. 4c, the values of band gap decreased from 1.09 to $1.03 \mathrm{eV}$ after the adsorption of $\mathrm{CuO}$. To further explore the reasons for photothermal enhancement, molecular models were constructed to calculate the change of the band gaps $[39,40]$. When $\mathrm{CuO}$ was adsorbed on CNSs, defects appeared on the surface of CNSs. DFT was employed to investigate the electronic structures of CNSs, defected CNSs, and CuO@CNSs, respectively, and the results are shown in Fig. 4d and Fig. S7a. There was a band gap near the Fermi level for CNSs, while it was reduced as the introduction of $\mathrm{C}$ defect. This result suggested that the defect in CNSs can improve the electronic transportation, which was the key factor to enhance the photothermal conversion efficiency of CNSs. However, the band gap disappeared when the $\mathrm{CuO}$ cluster was placed on the defect site. These results indicated that the CuO@CNSs showed higher photothermal conversion efficiency than CNSs, which was in agreement with the experimental observation. To further explore the mechanism of photothermal conversion of $\mathrm{CuO} @ \mathrm{CNSs}$, the partial densities of state of C-2p and $\mathrm{Cu}-3 \mathrm{~d}$ in the interface are revealed in Fig. S7b. The disappeared band gap was mainly from the $\mathrm{C}-2 \mathrm{p}$ and $\mathrm{Cu}-$ $3 \mathrm{~d}$, which were overlapped near the Fermi level. It can be 

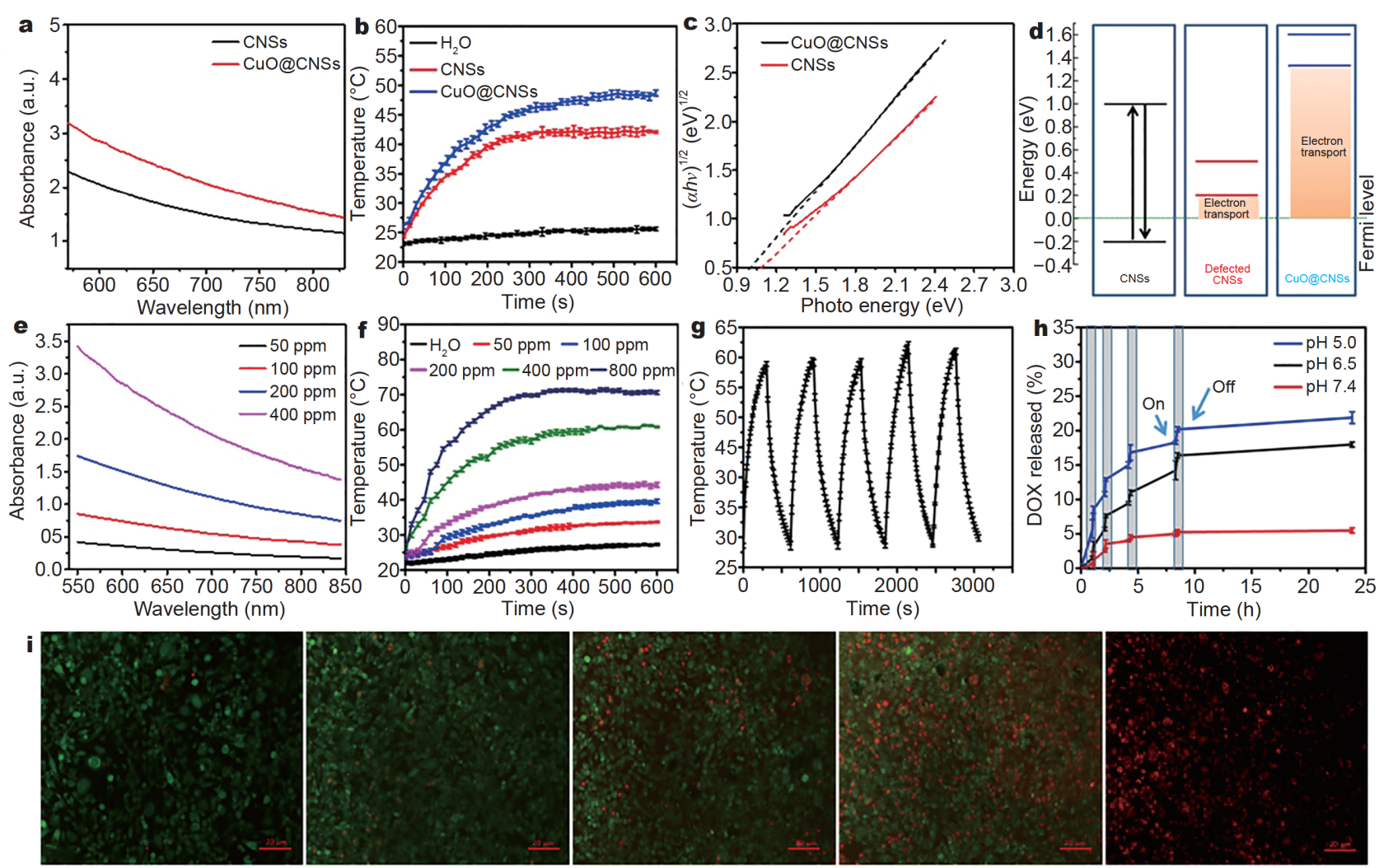

25 ppm

50 ppm

100 ppm

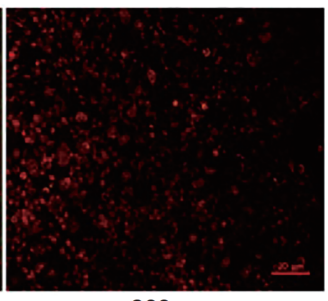

200 ppm

Figure 4 (a) The UV-Vis absorption spectra of CNSs and CuO@CNSs. (b) Temperature change curves of CNSs and CuO@CNSs with the same concentration under NIR irradiation $\left(808 \mathrm{~nm}, 2 \mathrm{~W} \mathrm{~cm}^{-2}, 10 \mathrm{~min}\right.$ ). (c) Optical bandgaps of CNSs and CuO@CNSs. (d) The energy levels of CNSs, defected CNSs and CuO@CNSs. (e) UV-Vis absorption spectra of CuO@CNSs with different concentrations. (f) Temperature change curves of CuO@CNSs with different concentrations under NIR irradiation (808 nm, 2 W cm $\left.{ }^{-2}, 10 \mathrm{~min}\right)$. (g) Temperature changes of the CuO@CNSs (400 ppm) over five On/Off cycles under 808-nm irradiation. (h) Released DOX from CuO@CNSs-DOX under 808-nm irradiation at different pH. (i) Fluorescence images of $4 \mathrm{~T} 1$ cells co-stained with calcein-AM and PI after incubation with different concentrations of CuO@CNSs and irradiation with $808-\mathrm{nm}$ NIR $\left(2 \mathrm{~W} \mathrm{~cm}^{-2}\right)$ for $10 \mathrm{~min}$.

deduced that the higher photothermal conversion efficiency of $\mathrm{CuO} @ \mathrm{CNSs}$ was due to the synergistic function between the $\mathrm{Cu}$ and $\mathrm{C}$. Fig. $4 \mathrm{e}$ and $\mathrm{f}$ reveal that the NIR absorption and the photothermal effect of solution are concentration-dependent. The temperature of $\mathrm{CuO} @ \mathrm{CNSs}$ solution reached up to $60.3^{\circ} \mathrm{C}$ from $23^{\circ} \mathrm{C}$ when the concentration was $400 \mathrm{ppm}$, while water displayed mild temperature increase (less than $5^{\circ} \mathrm{C}$ ). Besides, the photothermal effect of $\mathrm{CuO} @ \mathrm{CNSs}$ was stable (Fig. 4g). The above data proved that the CuO@CNSs have potential to be photothermal agents [41].

To further explore the photothermal performance, calcein-AM and PI were used to stain cancer cells after NIR irradiation to distinguish the dead (red) and live (green) cells, respectively (Fig. 4i). With the increase of concentration, the number of dead cells increased. So the concentration-dependent cytotoxicity confirmed that the $\mathrm{CuO@CNSs} \mathrm{can} \mathrm{be} \mathrm{used} \mathrm{for} \mathrm{PTT.}$

\section{DOX loading and releasing behavior}

DOX was loaded on the surface of $\mathrm{CuO} @ \mathrm{CNSs}$ via electrostatic adsorption, with a loading efficiency of $12 \%$. The cumulative drug release curves at different $\mathrm{pH}$ values are exhibited in Fig. 4h. 24\% and 15\% of DOX were released within $25 \mathrm{~h}$ at $\mathrm{pH} 5.0$ and 6.5, respectively [42-44], which are almost five and three times as much as the amount of DOX released at $\mathrm{pH}$ 7.4. The result indicated that the release of DOX was $\mathrm{pH}$-dependent. When exposed to 808 -nm laser irradiation for $10 \mathrm{~min}\left(2 \mathrm{~W} \mathrm{~cm}^{-2}\right)$, a burst and quick release of DOX was observed. But when the laser was shut off, the release rate immediately decreased. Importantly, the rapid release of DOX under NIR irradiation was attributed to the good photothermal effect of the CuO@CNSs.

\section{Celluar uptake assays}

Fluorescence microscope and ICP-MS were used to in- 
vestigate the cellular uptake of the NPs. As shown in Fig. $5 \mathrm{a}$, the endocytosis process was time-dependent and DOX gradually accumulated in cells with the increase of time. To further investigate the accumulation of nanoparticles in cells, ICP-MS was used to explore the concentrations of copper ions internalized by $4 \mathrm{~T} 1$ cells at different time points (10, 60 and $240 \mathrm{~min}$ ). In Fig. 5b, the contents of copper in $4 \mathrm{~T} 1$ cells after incubation with $\mathrm{CuO} @ \mathrm{CNSs}$ at 10,60 and $240 \mathrm{~min}$ were 9.88, 54.51 and $73.71 \mathrm{ng} \mathrm{Cu}$ per $10^{5}$ cells, respectively.

\section{In vitro cytotoxicity of $\mathrm{CuO} @ \mathrm{CNSs}$}

The biocompatibility of CuO@CNSs was measured by the standard MTT assay. We studied the viabilities of $4 \mathrm{~T} 1$ and L929 cells after incubation with $\mathrm{CuO} @ \mathrm{CNSs}$ at different concentrations. In Fig. 5e, the viability of the L929 cells was greater than $90 \%$ at the concentration of as high as $200 \mathrm{ppm}$, but when $4 \mathrm{~T} 1$ cells were incubated with the same concentration, the viability decreased to $65 \%$. The different survival rates were caused by the different $\mathrm{H}_{2} \mathrm{O}_{2}$ contents between $4 \mathrm{~T} 1$ and L929 cells [22].
The cytotoxicity of CuO@CNSs against 4T1 cells was also measured by the MTT assay. After incubation with CuO@CNSs, CuO@CNSs+NIR, pure DOX,CuO@CNSsDOX or CuO@CNSs-DOX+NIR for $24 \mathrm{~h}$, the cell viabilities are shown in Fig. $5 \mathrm{c}$. The viability of the cells treated with $\mathrm{CuO} @ \mathrm{CNSs}$ alone was 65\% at the concentration of $200 \mathrm{ppm}$, but when treated with CuO@CNSs+NIR at the same concentration, the viability decreased to $50 \%$, demonstrating the good photothermal effect of the CuO@CNSs. It is notable that the cells cultured with $\mathrm{CuO@CNSs-DOX+NIR} \mathrm{have} \mathrm{the} \mathrm{lowest} \mathrm{cell}$ viability of $18 \%$ compared with the other groups. The above results confirm that the multi-mode therapy has a better anti-tumor effect.

The apoptosis ratio of $4 \mathrm{~T} 1$ cells after different treatments was detected by flow cytometry (Fig. 5d). The CuO@CNSs-DOX+NIR group displayed 29\% of cell apoptosis, which is higher than CuO@CNSs-DOX (5.44\%), DOX (19.64\%), CuO@CNSs+NIR (21.02\%) and CuO@CNSs (8.98\%) groups, respectively. The above results proved that the multi-mode therapy can promote
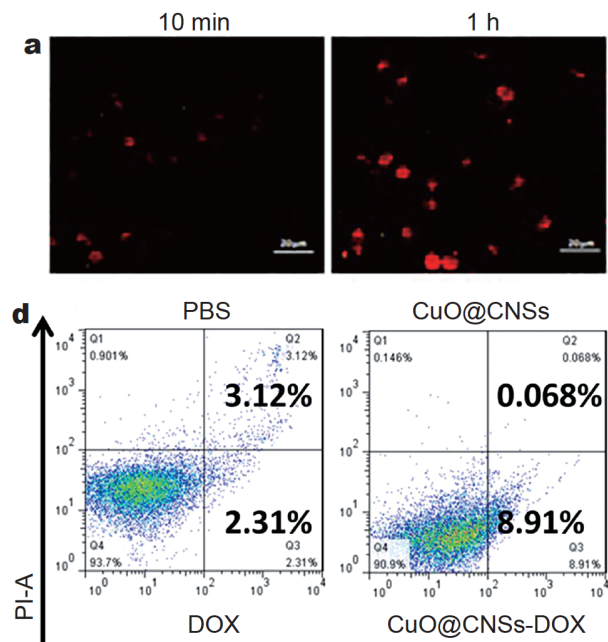

CUO@CNSs

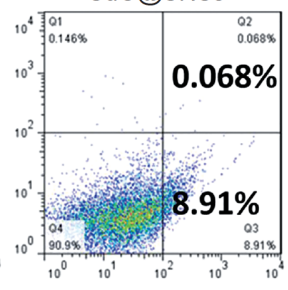

CuO@CNSs-DOX
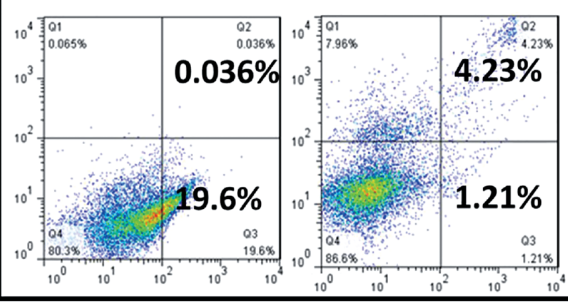
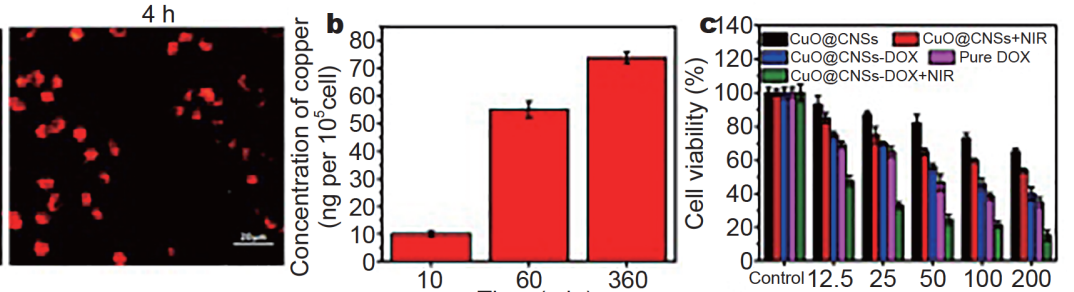

CUO@CNSS+NIR
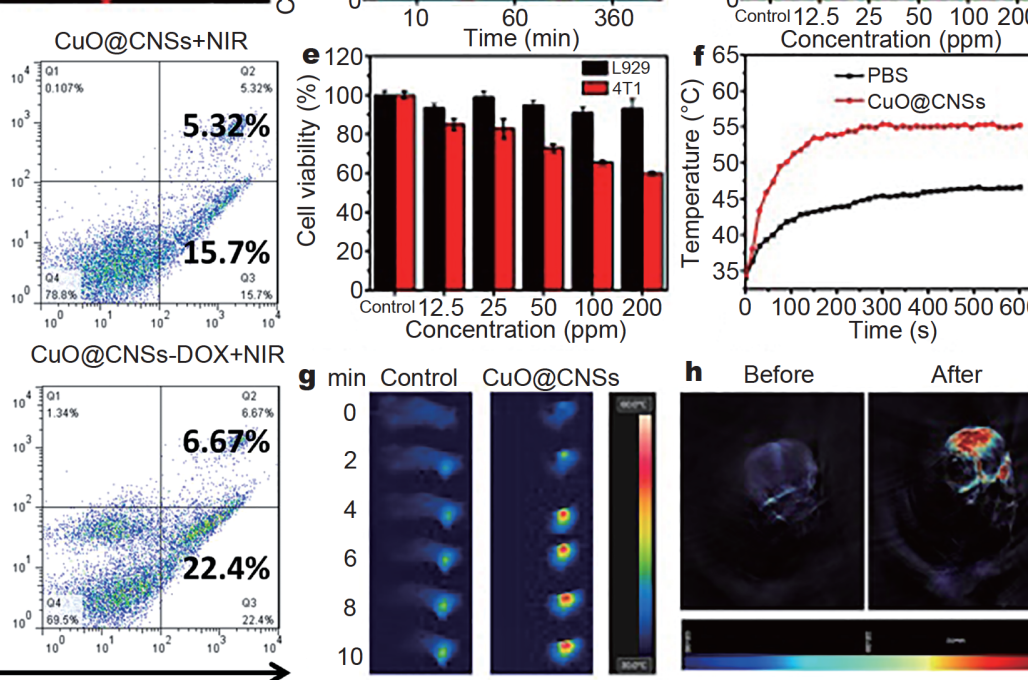

h Before
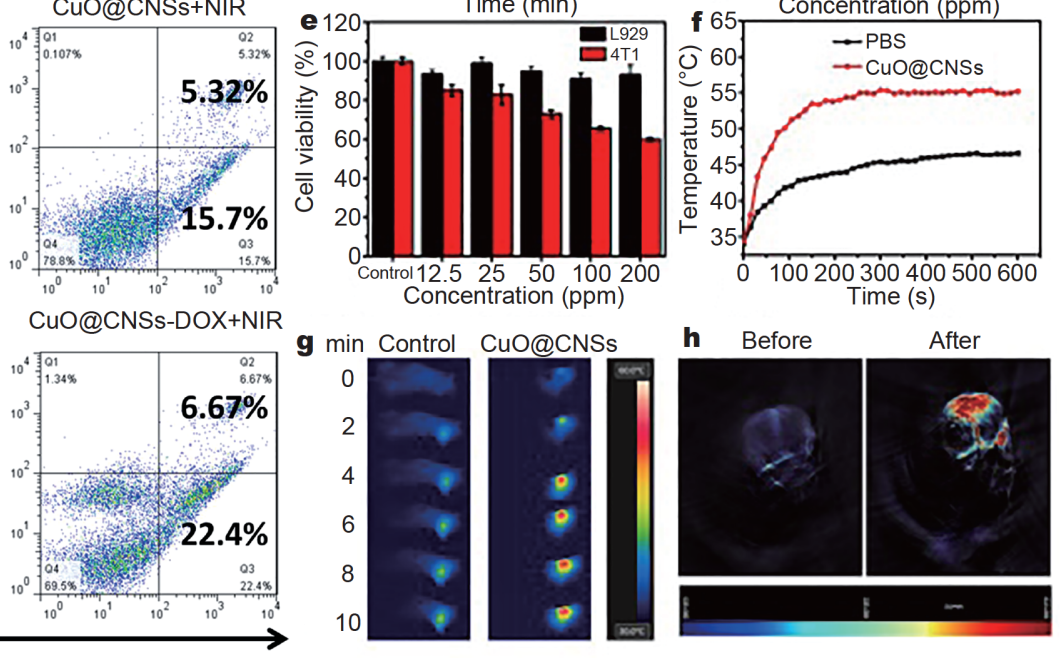

Figure 5 (a) Cellular uptake of CuO@CNSs-DOX in $4 \mathrm{~T} 1$ cells at different time points ( $10 \mathrm{~min}, 1 \mathrm{~h}$, and $4 \mathrm{~h}$ ). (b) Mass of copper internalized in $4 \mathrm{~T} 1$ cells after incubation with CuO@CNSs at different time points $(10 \mathrm{~min}, 1 \mathrm{~h}$, and $4 \mathrm{~h})$. (c) The cell viability of $4 \mathrm{~T} 1$ cells after various treatments, where the cells were exposed to $808-\mathrm{nm}$ laser $\left(2 \mathrm{~W} \mathrm{~cm}^{-2}\right.$ ) for $5 \mathrm{~min}$ or not. (d) Flow cytometric analyses of cell apoptosis. (e) The cell viability of $4 \mathrm{~T} 1$ and L929 cells incubated with CuO@CNSs. (f) Temperature plot and (g) the IR thermal images of 4T1 tumor-bearing mice after intratumoral injection of CuO@CNSs $\left(5 \mathrm{mg} \mathrm{mL}^{-1}, 0.1 \mathrm{~mL}\right)$ for $3 \mathrm{~h}$ and exposed to $808-\mathrm{nm}$ laser $\left(2 \mathrm{~W} \mathrm{~cm}^{-2}, 10 \mathrm{~min}\right)$. (h) PA images of tumor site before and after injection with CuO@CNSs. 
apoptosis and improve treatment efficiency.

\section{IR and PA bioimaging}

The in vivo IR thermal images of Balb/c mice injected with or without CuO@CNSs were taken. Fig. 5g and $\mathrm{f}$ show the surface temperature of the tumor was quickly increased by $20^{\circ} \mathrm{C}$ when the mice were treated with $\mathrm{CuO} @ \mathrm{CNSs}$ and irradiated with $808-\mathrm{nm}$ laser $\left(2 \mathrm{~W} \mathrm{~cm} \mathrm{~cm}^{-2}\right.$, $10 \mathrm{~min}$ ), which was much higher than the control group (increase of $10^{\circ} \mathrm{C}$ ). PA imaging, as a newly emerging bioimaging method, can provide noninvasive diagnosis of diseases based on ultrasound emission. The intensity of PA signal was related to the absorption strength of nanomaterials. As shown in Fig. S8, a good linear relationship was observed between the PA signal and nanoparticles concentration in vitro, suggesting that the $\mathrm{CuO} @ \mathrm{CNSs}$ can be used as an ideal PA imaging contrast agent for imaging-guided cancer diagnosis. For in vivo PA imaging (Fig. 5h), the tumor region showed weak PA signals before injection, but when the mice were intratumorally injected with $\mathrm{CuO} @ \mathrm{CNSs}$, the tumor region showed strong PA signals. The above results verified that $\mathrm{CuO} @ \mathrm{CNSs}$ were good contrast agents to offer guidance for determining the time window of tumor treatment [45-47].
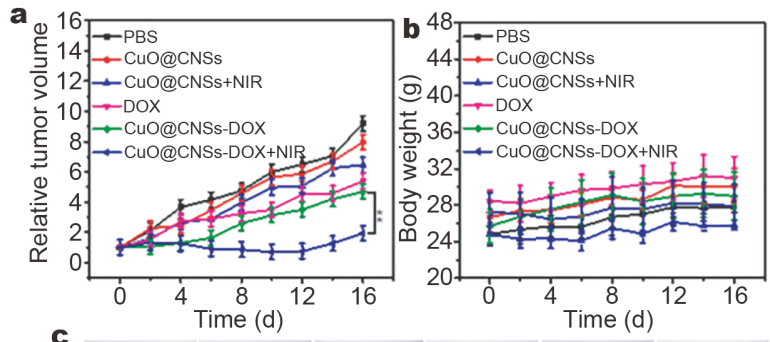

c

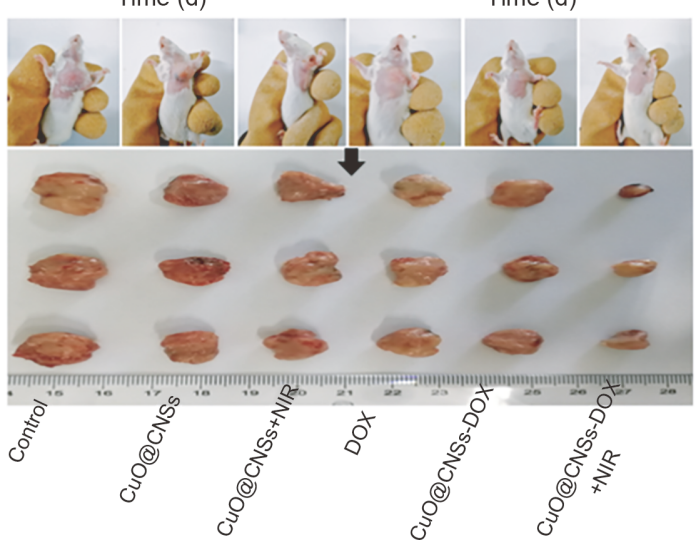

\section{In vivo antitumor efficacy}

The in vivo antitumor effect was explored by a $4 \mathrm{~T} 1$ tumor-bearing Balb/c mice model. First, we divided the tumor-bearing Balb/c mice into six groups (six mice in each group): (i) PBS $(0.1 \mathrm{~mL})$ only; (ii) $\mathrm{CuO@CNSs}$ (5 mg mL $\left.{ }^{-1}, 0.1 \mathrm{~mL}\right)$; (iii) $\mathrm{CuO@CNSs+NIR}\left(5 \mathrm{mg} \mathrm{mL}^{-1}\right.$, $0.1 \mathrm{~mL}, 808+, 10 \mathrm{~min})$; (iv) DOX $\left(680 \mu \mathrm{g} \mathrm{mL}^{-1}, 0.1 \mathrm{~mL}\right)$; (v) CuO@CNSs-DOX $\quad\left(5 \mathrm{mg} \mathrm{mL}^{-1}, \quad 0.1 \mathrm{~mL}\right) ; \quad$ (vi) CuO@CNSs-DOX+NIR $\quad\left(5 \mathrm{mg} \mathrm{mL}^{-1}, \quad 0.1 \mathrm{~mL}, \quad 808+\right.$, $10 \mathrm{~min}$ ). The tumor sizes and weights of the mice were measured every two days. As shown in Fig. 6a, tumors treated with PBS or CuO@CNSs showed negligible anticancer effect. Tumors treated with $\mathrm{CuO@CNSs+NIR,}$ CuO@CNSs-DOX or DOX exhibited moderate therapeutic effect. It is notable that when the mice were treated with CuO@CNSs-DOX+NIR, the growth of tumor was obviously inhibited, suggesting that the threemode therapy has an excellent effect. In Fig. 6b, there are no obvious changes of the body weights of mice. All of mice were sacrificed and the tumors were stripped at Day 16. As presented in Fig. 6c, the photographs show that the CuO@CNSs-DOX+NIR group has the best anti-cancer effect. The H\&E staining images of main organ slices of mice (heart, liver, spleen, lung, and kidney) were photographed after different treatments. As presented in

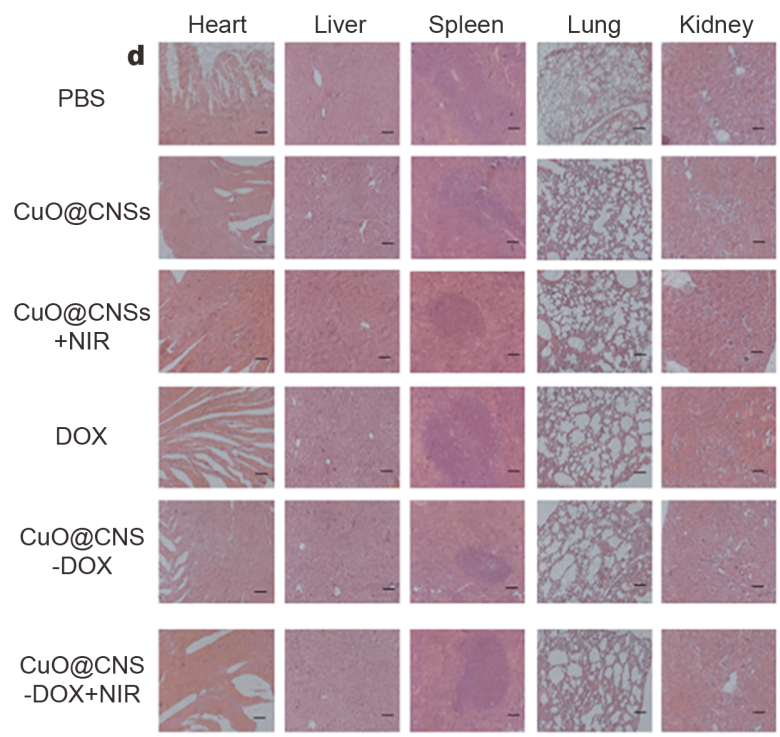

Figure 6 (a) Relative tumor volumes. (b) Body weights of Balb/c mice after various treatments. The mice were intratumorally injected with nanoparticles $\left(5 \mathrm{mg} \mathrm{mL}^{-1}, 0.1 \mathrm{~mL}\right)$ and irradiated with $808-\mathrm{nm}$ laser $\left(2 \mathrm{~W} \mathrm{~cm}^{-2}, 10 \mathrm{~min}\right)$. (c) Photographs of mice and tumors after various treatments. (d) H\&E staining images of the main organ slices of mice after various treatments. Scale bar is $20 \mu \mathrm{m}$. $* * p<0.01$. 
Fig. $6 \mathrm{~d}$, neither organ damage nor inflammatory lesion was detected, which proved the low toxicity of $\mathrm{CuO} @ \mathrm{CNSs}-\mathrm{DOX}$ in vivo. These results indicated that the multifunctional CuO@CNSs-DOX nanoplatforms have a high biosafety and anti-cancer effect.

\section{CONCLUSIONS}

In summary, we successfully synthesized multifunctional nanoplatforms CuO@CNSs-DOX to realize the combination therapy of PTT, CDT, and CT. CuO was adsorbed on the surface of CNSs, which improved the photothermal conversion efficiency of nanoparticles from $6.7 \%$ to $10.14 \%$. The enhancement of photothermal conversion efficiency was due to the electron transitions between C$2 \mathrm{p}$ and $\mathrm{Cu}-3 \mathrm{~d}$. In addition, $\mathrm{CuO}$ was also a $\mathrm{CDT}$ agent, which can release $\mathrm{Cu}^{2+}$ at the tumor site to produce $\cdot \mathrm{OH}$ via Haber-Weiss and Fenton-like reactions. Chemotherapeutic drug DOX was loaded on the surface of

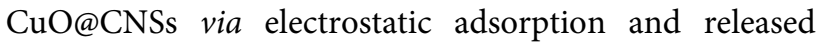
quickly at the tumor site to kill cancer cells. Besides, $\mathrm{CuO@CNSs} \mathrm{can} \mathrm{be} \mathrm{used} \mathrm{for} \mathrm{the} \mathrm{IR/PA} \mathrm{dual-modal}$ imaging to provide the real-time diagnosis for diseases. The excellent anti-tumor effect and high biosafety make the multi-mode nanoplatforms have great potential in biomedical applications.

Received 29 December 2019; accepted 17 May 2020;

published online 17 July 2020

1 Taratula O, Doddapaneni BS, Schumann C, et al. Naphthalocyanine-based biodegradable polymeric nanoparticles for imageguided combinatorial phototherapy. Chem Mater, 2015, 27: 61556165

2 Jing Z, Zhan J. Fabrication and gas-sensing properties of porous ZnO nanoplates. Adv Mater, 2008, 20: 4547-4551

3 Cheng L, Liu J, Gu X, et al. PEGylated $\mathrm{WS}_{2}$ nanosheets as a multifunctional theranostic agent for in vivo dual-modal CT/ photoacoustic imaging guided photothermal therapy. Adv Mater, 2014, 26: 1886-1893

4 Ge J, Jia Q, Liu W, et al. Red-emissive carbon dots for fluorescent, photoacoustic, and thermal theranostics in living mice. Adv Mater, 2015, 27: 4169-4177

5 Mao F, Wen L, Sun C, et al. Ultrasmall biocompatible $\mathrm{Bi}_{2} \mathrm{Se}_{3}$ nanodots for multimodal imaging-guided synergistic radiophotothermal therapy against cancer. ACS Nano, 2016, 10: 1114511155

6 Robinson JT, Tabakman SM, Liang Y, et al. Ultrasmall reduced graphene oxide with high near-infrared absorbance for photothermal therapy. J Am Chem Soc, 2011, 133: 6825-6831

7 Zhu X, Feng W, Chang J, et al. Temperature-feedback upconversion nanocomposite for accurate photothermal therapy at facile temperature. Nat Commun, 2016, 7: 10437

8 Xiang Y, Li N, Guo L, et al. Biocompatible and $\mathrm{pH}$-sensitive MnOloaded carbonaceous nanospheres (MnO@CNSs): A theranostic agent for magnetic resonance imaging-guided photothermal ther- apy. Carbon, 2018, 136: 113-124

9 Nandi S, Bhunia SK, Zeiri L, et al. Bifunctional carbon-dot-WS nanorods for photothermal therapy and cell imaging. Chem Eur J, 2017, 23: 963-969

10 Liu Y, Zhen W, Jin L, et al. All-in-one theranostic nanoagent with enhanced reactive oxygen species generation and modulating tumor microenvironment ability for effective tumor eradication. ACS Nano, 2018, 12: 4886-4893

11 Xu C, Wang Y, Yu H, et al. Multifunctional theranostic nanoparticles derived from fruit-extracted anthocyanins with dynamic disassembly and elimination abilities. ACS Nano, 2018, 12: 82558265

12 Feng L, Xie R, Wang C, et al. Magnetic targeting, tumor microenvironment-responsive intelligent nanocatalysts for enhanced tumor ablation. ACS Nano, 2018, 12: 11000-11012

13 Hureau C, Faller P. A $\beta$-mediated ROS production by $\mathrm{Cu}$ ions: Structural insights, mechanisms and relevance to Alzheimer's disease. Biochimie, 2009, 91: 1212-1217

14 Laggner $\mathrm{H}$, Hermann M, Gmeiner BMK, et al. $\mathrm{Cu}^{2+}$ and $\mathrm{Cu}^{+}$ bathocuproine disulfonate complexes promote the oxidation of the ROS-detecting compound dichlorofluorescin (DCFH). Anal Bioanal Chem, 2006, 385: 959-961

15 Rehman SU, Zubair H, Sarwar T, et al. Redox cycling of $\mathrm{Cu}$ (II) by 6-mercaptopurine leads to ROS generation and DNA breakage: Possible mechanism of anticancer activity. Tumour Biol, 2015, 36: 1237-1244

16 Ding $\mathrm{B}$, Shao $\mathrm{S}$, Jiang $\mathrm{F}$, et al. $\mathrm{MnO}_{2}$-disguised upconversion hybrid nanocomposite: An ideal architecture for tumor microenvironment-triggered UCL/MR bioimaging and enhanced chemodynamic therapy. Chem Mater, 2019, 31: 2651-2660

17 Assal ME, Shaik MR, Kuniyil M, et al. $\mathrm{Ag}_{2} \mathrm{O}$ nanoparticles $/ \mathrm{MnCO}_{3}$, $-\mathrm{MnO}_{2}$ or $-\mathrm{Mn}_{2} \mathrm{O}_{3}$ /highly reduced graphene oxide composites as an efficient and recyclable oxidation catalyst. Arabian J Chem, 2019, 12: 54-68

18 Wan SS, Cheng Q, Zeng X, et al. A Mn(III)-sealed metal-organic framework nanosystem for redox-unlocked tumor theranostics. ACS Nano, 2019, 13: 6561-6571

19 Park J, Lim DH, Lim HJ, et al. Size dependent macrophage responses and toxicological effects of $\mathrm{Ag}$ nanoparticles. Chem Commun, 2011, 47: 4382

20 Zhang X, Xi Z, Machuki JO, et al. Gold cube-in-cube based oxygen nanogenerator: A theranostic nanoplatform for modulating tumor microenvironment for precise chemo-phototherapy and multimodal imaging. ACS Nano, 2019, 13: 5306-5325

21 Liu B, Li C, Chen G, et al. Synthesis and optimization of $\mathrm{MoS}_{2} @$ $\mathrm{Fe}_{3} \mathrm{O}_{4}$-ICG/Pt(IV) nanoflowers for MR/IR/PA bioimaging and combined PTT/PDT/chemotherapy triggered by $808 \mathrm{~nm}$ laser. Adv Sci, 2017, 4: 1600540

22 Wu C, Wang S, Zhao J, et al. Biodegradable Fe(III)@WS 2 -PVP nanocapsules for redox reaction and TME-enhanced nanocatalytic, photothermal, and chemotherapy. Adv Funct Mater, 2019, 29: 1901722

23 Liu Y, Jia Q, Guo Q, et al. Simultaneously activating highly selective ratiometric MRI and synergistic therapy in response to intratumoral oxidability and acidity. Biomaterials, 2018, 180: 104116

24 Miao ZH, Wang H, Yang H, et al. Glucose-derived carbonaceous nanospheres for photoacoustic imaging and photothermal therapy. ACS Appl Mater Interfaces, 2016, 8: 15904-15910

25 Zhao M, Li B, Wang P, et al. Supramolecularly engineered NIR-II 
and upconversion nanoparticles in vivo assembly and disassembly to improve bioimaging. Adv Mater, 2018, 30: 1804982

26 Fan Y, Wang S, Zhang F. Optical multiplexed bioassays for improved biomedical diagnostics. Angew Chem Int Ed, 2019, 58: 13208-13219

27 Chen Z, Jiao Z, Pan D, et al. Recent advances in manganese oxide nanocrystals: Fabrication, characterization, and microstructure. Chem Rev, 2012, 112: 3833-3855

28 Kung ML, Tai MH, Lin PY, et al. Silver decorated copper oxide $(\mathrm{Ag} @ \mathrm{CuO})$ nanocomposite enhances ROS-mediated bacterial architecture collapse. Colloids Surfs B-Biointerfaces, 2017, 155: 399407

29 Yumoto F, Nara M, Kagi $\mathrm{H}$, et al. Coordination structures of $\mathrm{Ca}^{2+}$ and $\mathrm{Mg}^{2+}$ in Akazara scallop troponin $\mathrm{C}$ in solution. Eur J Biochem, 2001, 268: 6284-6290

30 Chen YW, Su YL, Hu SH, et al. Functionalized graphene nanocomposites for enhancing photothermal therapy in tumor treatment. Adv Drug Deliver Rev, 2016, 105: 190-204

31 Ferrari AC, Robertson J. Interpretation of Raman spectra of disordered and amorphous carbon. Phys Rev B, 1999, 61: 1409514107

32 Sobon G, Sotor J, Jagiello J, et al. Graphene oxide $v$ s. reduced graphene oxide as saturable absorbers for Er-doped passively mode-locked fiber laser. Opt Express, 2012, 20: 19463-19473

33 Guo S, Lu G, Qiu S, et al. Carbon-coated MnO microparticulate porous nanocomposites serving as anode materials with enhanced electrochemical performances. Nano Energy, 2014, 9: 41-49

34 Li J, Song Y, Ma Z, et al. Preparation of polyvinyl alcohol graphene oxide phosphonate film and research of thermal stability and mechanical properties. Ultrasons Sonochem, 2018, 43: 1-8

35 Mi P, Kokuryo D, Cabral H, et al. A pH-activatable nanoparticle with signal-amplification capabilities for non-invasive imaging of tumour malignancy. Nat Nanotech, 2016, 11: 724-730

36 Li M, Wang $\mathrm{Y}$, Lin $\mathrm{H}$, et al. Hollow $\mathrm{CuS}$ nanocube as nanocarrier for synergetic chemo/photothermal/photodynamic therapy. Mater Sci Eng-C, 2019, 96: 591-598

37 Huang CX, Chen HJ, Li F, et al. Controlled synthesis of upconverting nanoparticles/CuS yolk-shell nanoparticles for in vitro synergistic photothermal and photodynamic therapy of cancer cells. J Mater Chem B, 2017, 5: 9487-9496

38 Zhang MK, Wang XG, Zhu JY, et al. Double-targeting explosible nanofirework for tumor ignition to guide tumor-depth photothermal therapy. Small, 2018, 14: 1800292

39 Kresse G, Hafner J. Ab initio molecular-dynamics simulation of the liquid-metal-amorphous-semiconductor transition in germanium. Phys Rev B, 1994, 49: 14251-14269

40 Perdew JP, Burke K, Ernzerhof M. Generalized gradient approximation made simple. Phys Rev Lett, 1996, 77: 3865-3868
41 Yong Y, Cheng X, Bao T, et al. Tungsten sulfide quantum dots as multifunctional nanotheranostics for in vivo dual-modal imageguided photothermal/radiotherapy synergistic therapy. ACS Nano, 2015, 9: 12451-12463

42 Liang $\mathrm{S}$, Xie Z, Wei $\mathrm{Y}$, et al. DNA decorated $\mathrm{Cu}_{9} \mathrm{~S}_{5}$ nanoparticles as NIR light responsive drug carriers for tumor chemo-phototherapy. Dalton Trans, 2018, 47: 7916-7924

43 Song G, Wang Q, Wang Y, et al. A low-toxic multifunctional nanoplatform based on $\mathrm{Cu}_{9} \mathrm{~S}_{5} @ \mathrm{mSiO}_{2}$ core-shell nanocomposites: Combining photothermal- and chemotherapies with infrared thermal imaging for cancer treatment. Adv Funct Mater, 2013, 23: 4281-4292

44 Chen Y, Hou Z, Liu B, et al. DOX- $\mathrm{Cu}_{9} \mathrm{~S}_{5} @ \mathrm{mSiO}_{2}-\mathrm{PG}$ composite fibers for orthotopic synergistic chemo- and photothermal tumor therapy. Dalton Trans, 2015, 44: 3118-3127

45 Lei Z, Sun C, Pei P, et al. Stable, wavelength-tunable fluorescent dyes in the NIR-II region for in vivo high-contrast bioimaging and multiplexed biosensing. Angew Chem Int Ed, 2019, 58: 8166-8171

46 Zhou L, Fan Y, Wang R, et al. High-capacity upconversion wavelength and lifetime binary encoding for multiplexed biodetection. Angew Chem Int Ed, 2018, 57: 12824-12829

47 Wang S, Liu L, Fan Y, et al. In vivo high-resolution ratiometric fluorescence imaging of inflammation using NIR-II nanoprobes with $1550 \mathrm{~nm}$ emission. Nano Lett, 2019, 19: 2418-2427

Acknowledgements This work was supported by the National Natural Science Foundation of China (51720105015, 51672269, 51929201, 51922097, 51772124 and 51872282), the Science and Technology Cooperation Project between Chinese and Australian Governments (2017YFE0132300), the Science and Technology Development Planning Project of Jilin Province (20170101188JC and 20180520163JH), the Key Research Program of Frontier Sciences, CAS (YZDY-SSW-JSC018), the Youth Innovation Promotion Association of CAS (2017273), the Overseas, Hong Kong \& Macao Scholars Collaborated Researching Fund (21728101), and the CAS-Croucher Funding Scheme for Joint Laboratories (CAS18204).

Author contributions Jiang F performed the experiments and wrote the draft of manuscript; Ding B, Zhao Y and Liang S helped with the design of cell and animal experiments; Cheng Z, Xing B and Teng B provided suggestions and comments on the manuscript; Ma P and Lin J proposed the project and revised the manuscript.

Conflict of interest The authors declare that they have no conflict of interest.

Supplementary information Experimental details and supporting data are available in the online version of the paper. 


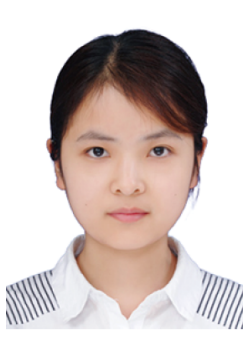

Fan Jiang received her BSc degree in chemistry from Zhengzhou University (ZZU) in 2017. She is currently a doctoral student under the supervision of Prof. Jun Lin at Changchun Institute of Applied Chemistry (CIAC), Chinese Academy of Sciences (CAS), and University of Science and Technology of China. Her research focuses on the development of inorganic nanoparticles for cancer therapy.

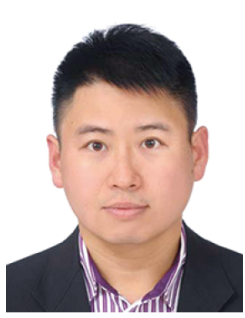

Ping'an Ma received his BSc degree in biology in 2005 and $\mathrm{PhD}$ degree in biochemistry in 2010, respectively, from Northeast Normal University. $\mathrm{He}$ is currently an assistant professor in Prof. Jun Lin's group at CIAC, CAS. His research focuses on the synthesis and application of multifunctional inorganic nanoparticles for bioapplication, particularly the design and mechanism of platinum-based anticancer drugs.

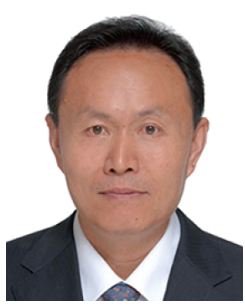

Jun Lin received BSc and MSc degrees in inorganic chemistry from Jilin University in 1989 and 1992, respectively, and a $\mathrm{PhD}$ degree (inorganic chemistry) from CIAC, CAS in 1995. He is currently a professor at CIAC, CAS. His research interests include luminescent materials and multifunctional composite materials as well as their applications in display, lighting and biomedical fields.

\section{$\mathrm{CuO}$ 修饰的碳纳米平台用于多重成像和联合增强} 的抗肿瘤治疗

姜帆 ${ }^{1,2}$, 丁涁彬 ${ }^{1,2}$, 赵雅洁 ${ }^{1,2}$, 梁双 ${ }^{1,2}$, 程子泳 ${ }^{1,2}$, 邢本刚 ${ }^{3}$, 滕博 ${ }^{4}$, 马平安 ${ }^{1,2^{*}}$, 林君 ${ }^{1,2^{*}}$

摘要 将多功能纳米平台的设计合成应用于肿瘤的联合治疗得到 研究人员的广泛关注. 本研究通过水热法制备了形貌均匀的光热 材料碳纳米球, 表面负载 $\mathrm{CuO}$ 和抗癌药盐酸阿霉素 $(\mathrm{DOX})$ 实现光 热/化学动力/化疗联合治疗. $\mathrm{CuO}$ 通过静电吸附负载在碳纳米球 (CNSs) 表面, 电子在C- $2 \mathrm{p}$ 与 $\mathrm{Cu}-3 \mathrm{~d}$ 之间的跃迁提高了材料的光热转 换效率. $\mathrm{CuO}$ 也可以作为化学动力试剂, 在肿瘤部位释放 $\mathrm{Cu}^{2+}$ 并通 过Haber-Weiss和类Fenton反应产生差基自由基诱导肿瘤细胞凋 亡. DOX吸附在CuO@CNSs表面, 表现出 $\mathrm{pH}$ 响应释放和近红外激 光刺激响应的释放效果. 研究结果表明, CuO@CNSs-DOX纳米平 台在体内外都有很好的抗癌效果, 在肿瘤治疗方面有很大的应用 潜力. 